\title{
KEPEMIMPINAN SANG JUARA KEPALA SD JAWA TENGAH
}

\author{
Slameto \\ Program Studi S1 PGSD FKIP Universitas Kristen Satya Wacana
}

\begin{abstract}
ABSTRAK
Kepemimpinan kepala sekolah sangat berpengaruh/menentukan keberhasilan siswa dan kemajuan sekolah; Oleh karena itu, kepemimpinan kepala sekolah perlu mendapat perhatian serius dalam peningkatan mutu pendidikan. Bagaimana pengalaman 35 kepala SD dalam kepemimpinan mereka sehingga berhasil menjadi juara aras Kabupaten/Kota di Jawa Tengah dan faktor apa saja yang mempengaruhinya? Data dikumpulkan melalui wawancara/diskusi terfokus saat para kepala sekolah mengikuti seleksi kejuaraan aras Jawa Tengah. Kepemimpinan kepala SD juara yang paling strategis adalah: bekerja langsung bersama guru untuk meningkatkan kualitas pembelajaran, menyediakan sumber dan sarana/prasarana yang memadai diimbangi dengan pengembangan profesional guru, secara periodik memantau perkem-bangan guru dalam mengajar dan keberhasilan siswa dalam belajar, memfasilitasi guru dalam kegiatan ilmiah, dan penggalangan partisipasi orang tua dan masyarakat. Kepemimpinan kepala SD juara ternyata dipengaruhi oleh 3 faktor yaitu: kepribadian, pemahaman/pengetahuan dan keterampilan sesuai tugas pokok dan fungsinya. Faktor kebijakan pendidikan ternyata tidak berpengaruh; penguasaan mereka terhadap esensi kebijakan dan implementasinya masih belum memuaskan.
\end{abstract}

Kata kunci: kepemimpinan kepala sekolah, kinerja sekolah, prestasi belajar siswa.

\section{PENDAHULUAN}

Masalah utama pendidikan di Indonesia hingga saat ini adalah rendahnya mutu pendidikan, khususnya pendidikan dasar dan menengah (Depdiknas 2002; Suparman 2001). Mutu pendidikan di Indonesia memang sangat rendah. Laporan UNDP tentang Human Development Index (HDIUNDP) tahun 2000 menempatkan peringkat mutu pendidikan Indonesia pada urutan 109 (Hariyono 2005). Mutu pendidikan Indonesia pada tahun 2004 turun menjadi peringkat 111, tahun 2005 berada pada peringkat 110 dari 177 negara. Rendahnya mutu pendidikan ini diperkuat hasil survey Political and Economic Risk Consultant (PERIC) menempatkan kualitas pendidikan di Indonesia pada urutan ke 12 diantara 12 negara di Asia.

Rendahnya mutu setiap jenjang dan satuan pendidikan, khususnya pendidikan dasar dan menengah seperti diungkapkan di atas, merupakan salah satu masalah yang kita hadapi dewasa ini (cf Depdiknas 2002). Paling tidak, ada 3 faktor yang menyebabkan rendahnya mutu dan ketidakmerataan peningkatan mutu pendidikan, yaitu: 1) kebijakan dan penyelenggaraan pendidikan nasional menggunakan pendekatan educational production function, tidak dilaksanakan secara konsekuen, 2) penyelenggaraan pendidikan dilakukan secara sentralistik, dan 3) parti-si-pasi masyarakat, khususnya orang tua siswa dalam penyelenggaraan pendidikan selama ini sangat minim (Depdiknas 2002). Menurut penulis, masalah rendahnya mutu pendidikan tersebut, sebetulnya terutama terletak pada masalah manajemen pendidikan (cf Satmoko 1999) pada aras sekolah, terutama manajemen sekolah oleh kepala sekolah; lebih spesifik lagi adalah kepemimpinan kepala sekolah (cf Dharma 2006)

Salah satu cara yang ditempuh oleh bangsa Indonesia untuk meningkatkan mutu pendidikan adalah dengan mengeluarkan kebijakan reformasi orientasi penyelenggaraan pendidikan, dari 
manajemen peningkatan mutu berbasis pusat, menuju manajemen peningkatan mutu berbasis sekolah (MPMBS). Sebagai salah satu bentuk inovasi dan atau reformasi pendidikan, manajemen berbasis sekolah (MBS) pada hakikatnya merupakan langkah untuk meningkatkan kemandirian (otonomi) dan profesional-isme setiap sekolah. Sekaligus, MBS mengembalikan hakikat keberadaan dan pengelolaan sekolah, agar mengakar pada kebutuhan masyarakatnya (Abu-Duhou 2002; Depdiknas 2002; cf Fattah 2003).

Direktorat Pendidikan Menengah Umum (2005) menyatakan bahwa 'inovasi manajemen pendidikan yang dilaksanakan sekarang ini berfokus pada reformasi pendidikan melalui MBS menuju budaya mutu'. Pelaksanaan kebijakan MBS memiliki landasan kokoh, karena sudah masuk dalam UU tentang Sistem Pendidikan Nasional pasal 51. Oleh sebab itu, pelaksanaannya harus disesuaikan dengan jiwa dan semangat otonomi. Kebijakan tersebut penulis anggap tepat, karena sesuai dan berdasar pada hasil analisis manajemen pendidikan (cf Satmoko, 1999).

Salah satu tujuan reformasi/inovasi pendidikan adalah peningkatan mutu pendidikan di sekolah. Kemudian, peningkatan mutu pendidikan akan tampak dari kualitas hasil belajar siswa. Untuk mewujudkan semua itu, mulai diterapkanlah MBS pada jenjang SD, kemudian pada semua jenjang, dan jenis sekolah. Konsep MBS menawarkan kerjasama yang erat antara sekolah, masyarakat, dan pemerintah. Sudah barang tentu, sesuai dengan tanggung jawab masing-masing. Konsep MBS ini berkembang berdasar pada suatu keinginan pemberian kemandirian kepada sekolah, untuk ikut terlibat secara aktif dan dinamis dalam rangka proses peningkatan kualitas pendidikan, melalui manajemen sumber daya sekolah yang ada (Fattah 2003; UUSPN 2003).

Sekolah harus mampu menerjemahkan dan menangkap esensi kebijakan makro pendidikan, dan memahami kondisi lingkunganya (kelebihan dan kekurangannya). Kemudian, melalui proses perencanaan, sekolah harus memformulasikannya ke dalam kebijakan mikro, dalam bentuk programprogram prioritas yang harus dilak-sanakan dan dievaluasi oleh sekolah yang bersangkutan, sesuai dengan visi dan misinya. Sekolah juga harus menentukan target mutu untuk tahun ajaran berikutnya. Dengan demikian, sekolah dapat bersikap mandiri, tetapi masih mengacu pada kebijakan nasional. Terlebih lagi, sekolah ditunjang oleh penyediaan input yang memadai, memiliki tanggung jawab terhadap pengembangan sumber daya yang dimiliki, sesuai dengan kebutuhan belajar siswa, orang tua, dan masyarakat.

MBS memiliki tiga pilar utama, yaitu: transparansi dan partisipasi manajemen kepala sekolah, pembelajaran aktif, kreatif, efektif dan menyenangkan, dan partisipasi orang tua. Guna mendukung keberhasilan MBS telah dilakukan serangkaian penataran, terutama menyangkut penegakan pilar pertama dan kedua, bagi kepala sekolah dan guru. Hal itu merupakan inti dari manajemen pendidikan yang berbasis pada sekolah untuk pemberdayaan sekolah, dan peningkatan prestasi belajar siswa.

Manajemen pendidikan terkait dengan berbagai usaha yang dilakukan kepala sekolah untuk meningkatkan mutu pendidikan, misalnya, melalui pengembangan kurikulum nasional dan kurikulum lokal (manajemen kurikulum), peningkatan kompetensi guru melalui pelatihan (manajemen personalia/SDM), pengadaan buku dan alat pelajaran, pengadaan dan perbaikan sarana dan prasarana (manajemen sarana dan prasarana) (cfDepdiknas 2002). Namun dalam penerapannya, hasilnya tidak memuaskan, belum menunjukkan peningkatan mutu yang merata. Sebagian sekolah, terutama di perkotaan, menunjukkan peningkatan mutu yang cukup menggembirakan, namun, sebagian di daerah lainnya masih memprihatinkan.

Pada tahun 2009 ini, di Jawa Tengah, telah dilakukan pemilihan kepala SD berprestasi yang dijaring mulai dari juara aras kecamatan kemudian yang berhasil dijaring pada aras kabupaten/ 
kota untuk menetapkan juaranya. Dengan demikian terdapat 35 orang kepala SD Juara I. Dari 35 orang Kepala SD Juara I, pastilah memiliki pengalaman berprestasi unik yang mengantarkannya menjadi juara. Bagaimana pengalaman 35 kepala SD dalam kepemimpinan mereka sehingga berhasil menjadi juara dalam pemilihan kepala SD berprestasi di aras Kabupaten/Kota di Jawa Tengah? Bagaimana mereka berprestasi dalam mengembangkan SD? dan faktor-faktor apa saja yang menjadi latar belakang kepemimpinan mereka sehingga berprestasi/menjadi juara?

Guna mengumpulkan data, pada saat 35 kepala SD mengikuti lomba aras Provinsi, dilakukan wawancara (tidak terstruktur) dalam diskusi kelompok terfokus (FGD) tentang pengalaman memimpin SD sehingga menang di daerahnya masing-masing; Kiat-kiat atau strategi apa yang mereka tempuh dan faktor pendukung apa saja yang ditemukan dalam menjalankan tugas pokok dan fungsinya sebagai kepala SD sehingga terpilih sebagai juara I Kepala SD berprestasi di daerahnya masing-masing.

\section{KEPEMIMPINAN KEPALA SEKOLAH DAN PENGARUHNYA TERHADAP KUALITAS SD}

Kepemimpinan adalah cara atau usaha kepala sekolah dalam mempengaruhi, mendorong, membimbing, mengarahkan, dan menggerakkan guru, staf, siswa, orangtua siswa, dan pihak lain yang terkait untuk bekerja/berperan-serta guna mencapai tujuan yang telah ditetapkan (cf Martono 2007; cf Mulyasa 2007; Slameto 2007). Singkatnya, bagaimana cara kepala sekolah untuk "membuat" orang lain bekerja untuk mencapai tujuan sekolah. Sehubungan dengan jabatannya, minimal terdapat 3 peran kepala sekolah yaitu sebagai pemimpin sekolah, manajer dan administrator (Martono 2007). Sebagai pemimpin, kepala sekolah mengarahkan, mempengaruhi, memberi pengertian dan atau sejenisnya kepada guru dan ataf untuk bekerja mencapai tujuan.

Kepemimpinan kepala sekolah memiliki peran strategis dalam kerangka menajemen dan kepala sekolah merupakan salah satu faktor terpenting dalam menunjang keberhasilan sekolah (cf Mulyasa 2007; Sutomo 2006). Kepemimpinan kepala sekolah- sangat berpengaruh dan bahkan sangat menentukan keberhasilan siswa dan kemajuan sekolah (Martono 2007; Mulyasa 2007). Kepala sekolah adalah pengelola satuan pendidikan yang bertugas menghimpun, memanfaatkan, mengoptimalkan seluruh potensi dan SDM, sumber daya lingkungan (sarana dan prasarana) serta sumber dana yang ada untuk membina sekolah dan masyarakat sekolah yang dikelolanya. Agar berhasil memimpin sekolah berprestasi, kepala sekolah perlu memahami dan menyadari bahwa keberadaan sekolahnya merupakan organisasi yang kompleks dan unik, serta mampu melaksanakan 3 peran sebagai pemimpin sekolah, manajer dan administrator (Martono 2007).

Secara umum terdapat sepuluh prinsip kepemimpinan kepala sekolah yang berlaku (Slameto 2007), yaitu: Konstruktif, artinya kepala sekolah harus mendorong dan membina setiap staf untuk berkembang secara optimal; Kreatif, artinya kepala sekolah harus selalu mencari gagasan dan cara baru dalam melaksanakan tugasnya; Partisipatif, artinya mendorong keterlibatan semua pihak yang terkait dalam setiap kegiatan di sekolah; Kooperatif, artinya mementingkan kerjasama dengan staf dan pihak lain yang terkait dalam melaksanakan setiap kegiatan; Delegatif, artinya berupaya mendelegasikan tugas kepada staf, sesuai dengan deskripsi tugas/jabatan serta kemampuan mereka; Integratif, artinya selalu mengintegrasikan semua kegiatan, sehingga dihasilkan sinergi untuk mencapai tujuan sekolah; Rasional dan obyektif, artinya dalam melaksanakan tugas atau bertindak, selalu berdasarkan pertimbangan rasional dan obyektif; Pragmatis, artinya dalam menetapkan kebijakan atau target, kepala sekolah harus mendasarkan pada kondisi dan kemampuan nyata yang dimiliki sekolah; Keteladanan, artinya dalam memimpin sekolah, kepala sekolah dapat menjadi 
contoh yang baik; Adaptabel dan fleksibel, artinya kepala sekolah harus dapat beradaptasi dan fleksibel dalam menghadapi situasi baru dan juga menciptakan situasi kerja yang memudahkan staf untuk beradaptasi.

Agar berhasil, menurut Darling-Hammond, LaPointe, Meyerson, Orr \& Cohen (2007), dalam pelaksanaan kepemimpinannya yang mendukung peningkatan kualitas pembelajaran gurunya, kepala sekolah perlu bekerja sama langsung dengan guru untuk meningkatkan kualitas pembelajaran di kelas, yang disertai dengan penyediaan sumber dan sarana/prasarana yang memadai serta mengimbangi dengan program pengembangan profesional guru; Selain itu kepala sekolah secara periodik memantau perkembangan guru dalam mengajar dan memantau keberhasilan siswa dalam belajar; menfasilitasi guru dalam kegiatan ilmiah yang terkait dengan peningkatan kualitas pendidikan; demi kemajuan sekolah, kepala sekolah juga perlu menyelenggarakan kegiatan ilmiah sepeerti in house training; penggalangan partisipasi orang tua dan masyarakat dalam pendidikan/ pembelajaran.

Darling-Hammond, LaPointe, Meyerson, Orr \& Cohen (2007) lebih lanjut menyata-kan bahwa kepemimpinan kepala sekolah yang mempengaruhi prestasi belajar siswa itu minimal melalui 2 jalur yang memoderatori yaitu: Pertama melalui proses seleksi, yang disertai dengan dukungan dan pengembangan guru dalam pengajarannya, dan kedua melalui proses kegiatan yang berdampak secara organisasional seperti prosedur dan pengembangan 'masyarakat pembelajar', perencanaan aras sekolah dan kelas, pengembangan kurikulum, pembelajaran dan penilaian.

Berdasarkan hasil penelitian dengan meta analisis atas studi lebih dari 30 tahun, Waters, Marzano, dan McNulty (2003) berhasil mengidentifikasi 21 tanggung jawab kepemimpinan kepala sekolah yang secara signifikan berpengaruh terhadap prestasi belajar siswa, yaitu: Culture, Order, Discipline, Resources, Curriculum, instruction, assesment, Focus, Knowledge of curriculum, instruction, assesment, Visibility, Contingent, Rewards, Communication, Outreach, Input, Affirmation, Relationship, Change agent, Optimizer, Ideals/beliefs, Monitors/evaluates, Flexibility, Situational awareness, dan Intellectual stimulation (cf Mulyasa 2007).

Apa saja yang dilakukan kepala sekolah yang efektif? Berdasarkan hasil studi DarlingHammond, LaPointe, Meyerson, Orr \& Cohen (2007) disarankan 4 hal kritis yang harus menjadi fokus yaitu: 1) melalui konsensus dalam penetapan visi, tujuan dan arah kebijakan; 2) membantu setiap guru secara individual melalui dukungan, keteladanan dan supervisi; 3) perencanaan dan perencanaan ulang organisasi sekolah yang memberi peluang kerjasama keluarga dan masyarakat; dan 4) pengelolaan organisasi sekolah dengan manajemen strategik dalam pengalokasian sumber dan bantuan yang ada dan dapat diadakan.

Darling-Hammond, LaPointe, Meyerson, Orr \& Cohen (2007) lebih lanjut menyatakan bahwa: penetapan visi dan pemberian dukungan kepada guru dan staf serta budaya yang selalu siap membantu, dipertahankannya pengambilan keputusan paritisipatif, dukungan stimulan intelektual dan harapan untuk berprestasi tinggi di kalangan guru dan siswa merupakan faktor penentu yang kuat atas 'organisasi pembelajar' yang secara langsung berpengaruh terhadap kinerja guru seperti motivasi dan pemberdayaannya yang pada gilirannya meningkatkan prestasi belajar siswa.

Keberhasilan kepemimpinan kepala sekolah sangat dipengaruhi hal-hal yang menyangkut kualitas pribadi, pengetahuan dan keterampilan (Slameto 2007): Kepribadian yang kuat; Kepala sekolah harus mengembangkan pribadi yang: percaya diri, berani, bersemangat, murah hati, dan memiliki kepekaan sosial. Memahami tujuan pendidikan dengan baik. Pemahaman yang baik merupakan bekal utama kepala sekolah agar dapat menjelaskan kepada guru dan staf, siswa dan 
pihak lain, serta menemukan strategi yang tepat untuk mencapainya. Pengetahuan yang luas. Kepala sekolah harus memiliki pengetahuan yang luas tentang bidang tugasnya maupun bidang lain yang terkait. Keterampilan profesional yang terkait dengan tugasnya sebagai kepala sekolah: keterampulan teknis, misalnya menyusun jadwal pelajaran, mensupervisi pengajaran, memimpin rapat dan seterusnya; keterampilan hubungan kemanusiaan, misalnya bekerjasama dengan orang lain, memotivasi dan mendorong guru dan staf dan seterusnya, dan keterampilan konseptual, misalnya mengembangkan konsep pengembangan sekolah, memperkirakan masalah yang akan muncul \& mencari pemecahannya.

\section{PENGALAMAN KEPEMIMPINAN KEPALA SD JUARA}

Berdasarkan hasil wawancara semi terstruktur dengan kepala SD sehubungan dengan pengalaman mereka dalam kepemimpinan sehingga berhasil menjadi juara adalah terangkum sebagai berikut.

1. Pengalaman kami sebagai kepala sekolah adalah mengakomodasikan semua guru yang mempunyai watak, ide, gagasan berbeda, sehingga guru bisa bekerja sesuai tugas pokok dan fungsinya secara maksimal. Berkomunikasi dengan guru, orang tua, masyarakat maupun kepada stakeholder, memahami kondisi guru, maupun staf, memberikan reward terhadap guru yang berprestasi. misalnya jika seorang guru mempunyai kompetensi di bidang seni maka sebagai kepala sekolah harus dapat memberdayakan guru tersebut untuk mengembangkan bidang seni di sekolah dan mana kala berhasil, memberi penghargaan kepadanya.

2. Pengalaman kepala sekolah sebagai pemimpin dihadapan para guru, ditengah-tengah mereka, bekerjasama dan menjadi motivasi dari belakang mereka dengan tetap berwibawa dihadapan para yang dipimpinnya, bertanggung dan penuh bijaksana. Dapat membuat sekolah yang kondusif baik untuk PBM, pengembangan karir guru maupun untuk kepala sekolah. Memotivasi guru agar berinovasi, memberi kesempatan untuk menambah/ mengembangkan profesinya dengan membantu serta mendukung guru mengikuti pelatihan, seminar, lokakarnya, penataran.

3. Kami membuat program kunjungan kelas untuk memantau kemajuan guru dalam mengajar dan program kunjungan lapangan untuk memberi pengalaman yang sebanyak-banyaknya kepada anak-anak di sekolah. Contoh: Ke Rumah Sakit, hotel, Penerbit Koran Kedaulatan Rakyat, dan lain-lain yang kemudian didiskusikan hasilnya.

4. Membantu serta mendukung guru mengikuti pelatihan, seminar, lokakarnya, penataran dan menjadwalkan guru untuk mengikuti dan berperan-serta dalam kegiatan KKG. Mengadakan studi banding ke SD lain yang lebih maju.

5. Kepala sekolah harus memiliki wibawa. Kewibawaan ini akan muncul dari sikap kepala sekolah yang terbuka menerima kritik dan saran, berperilaku yang sopan, memberikan teladan bagi para warga sekolah. Memberdayakan sumber daya sekolah; memaksimalkan partisipasi masyarakat dalam pengelolaan sekolah melalui pendekatan yang sesuai kultur masyarakat. Yang terpenting kepala sekolah "tidak memegang uang” sekolah, hal inilah yang saya lakukan.

\section{BAGAIMANA KEPALA SD BERPRESTASI DALAM MENGEMBANGKAN SD?}

Berdasarkan hasil wawancara semi terstruktur dengan kepala SD sehubungan dengan bagaimana mereka sebagai kepala sekolah berhasil mengembangkan SD sehingga menjadi juara adalah terangkum sebagai berikut. 
1. Seleksi alamiah rasanya yang terjadi dan saya alami. Sebagai kepala sekolah saya harus mampu mengadakan pembaharuan di SD yang saya pimpin dan harus berani bertanggung jawab menanggung resiko pada kebijakan yang saya buat dan dilaksanakan bersama. Mampu mengikuti perkembangan IPTEK dan Seni. Sesuai perubahan perkembangan jaman, perkem-bangan IPTEK untuk kemajuan SD saya, sebagai contoh: dalam menerima perkembangan IPTEK yang saya lakukan demi kemajuan sekolah; Karena guru-guru kami belum mengenal komputer, kami belikan seperangkat komputer dan secara bergantian, satu guru kami mengikuti kursus komputer dengan subsidi dari sekolah. Setelah bisa ditularkan pada guru lain, sehingga sekarang guru kami bisa mencari berita-berita di internet yang berhubungan dengan pendidikan, dan secara tidak langsung berdampak pada kualitas pembelajarannya.

2. Proses kegiatan yang berdampak secara organisasional seperti:

a. Mulai dari keberanian saya menerobos ke depan, untuk mencari pembaharuan-pembaharuan yang ada hubungannya dengan kemajuan pendidikan di sekolah. Kepala sekolah harus bisa menggerakkan kinerja guru dan warga sekolah, kepala sekolah harus bisa dijadikan figur, panutan bagi bawahannya. Dalam pengambilan keputusan harus dimusyawarahkan secara bersama-sama. Sebagai kepala sekolah saya harus bisa mengambil kebijakan dengan arif sehingga semua pihak bisa menerima dengan baik. Kepemimpinan saya hanya akan berhasil apabila mendapat dukungan dari semua pihak. Salah satu contoh, disiplin dalam berangkat, kepala sekolah harus berangkat lebih awal dari guru dan siswanya.

b. Contoh, di sekolah kami program olimpiade menjadi kebanggaan di tingkat kota, padahal dari pihak sekolah tidak mampu memberi imbalan yang tinggi terhadap pelatih yang didatangkan dari pihak lain, maka semua kebutuhan itu dibuat dalam perencanaan yang dituangkan dalam RAPBS sehingga tidak mengalami kendala dalam hal pembiayaan.

c. Dalam mengembangkan sekolah, saya mulai dari memotivasi guru dan siswa agar berinovasi, berani memutuskan untuk berubah dan selalu mengikuti perkembangan dengan kemajuan ilmu pengetahuan dan teknologi. Dengan cara begitu akan dapat meningkatkan kedisiplinan semua warga sekolah, meningkatkan kualitas pembelajaran yang akhirnya dapat meningkatkan kualitas out put. Contoh untuk meningkatkan intensitas belajar siswa dengan melaksanakan program pemberian "menu pagi" berupa rangsangan untuk memotivasi siswa. Selain itu saya selalu melakukan pembaharuan di SD dengan menemukan metode pembelajaran yang efektif, mendorong guru untuk menggunakan multi media dan alat-alat peraga dalam pembelajaran. Contoh, saya berusaha untuk selalu berpikiran kreatif untuk menciptakan situasi sekolah yang kondusif dan selalu ada peningkatan prestasi baik dalam bidang akademik/non akademik. Dalam rangka meningkatkan semangat kebangsaan dilaksanakan kegiatan pra pembelajaran yang berisi antara lain pengucapan ikrar siswa, menyanyikan lagu Wajib Nasional seperti Bagimu Negeri dll. Pada akhir pelajaran menyanyikan lagu Wajib Nasional. Dalam rangka menanamkan budi pekerti luhur dilakukan pembinaan dengan strategi yang sesuai dengan perkembangan anak, misalnya mendongeng dan lain-lain.

\section{FAKTOR YANG MEMPENGARUHI KEBERHASILAN PARA KEPALA SD}

Berdasarkan hasil wawancara semi terstruktur dengan kepala SD dalam forum diskusi kelas sehubungan dengan faktor-faktor yang mempengaruhi keberhasilan kepala sekolah mengembangkan SD sehingga menjadi juara adalah terangkum sebagai berikut. 
1. Mempunyai pribadi yang kuat misalnya jujur, bertanggung jawab, demokratis, transparan, berwibawa, pantang menyerah, bersikap adil kepada teman sekerja dan tidak diskriminatif, juga berperilaku yang baik dan bertanggung jawab dalam tugasnya. Mampu mengambil keputusan dengan baik, dalam arti keputusan yang diambil diterima oleh semua pihak serta didukung dalam pelaksanaannya. Dengan begitu dapat membuat sekolah yang kondusif.

2. Memahami visi dan misi sekolah; Dengan memahami visi dan misi sekolah, kepala sekolah berusaha meningkatkan mutu sekolah bersama guru dan stakeholder pendidikan melalui serangkaian program-program pengembangan SD.

3. Sebagai pemimpin, kepala sekolah harus tegas dalam memberikan suatu keputusan, disisi lain harus bersifat seorang bapak atau seorang teman. Contoh: kalau ada guru yang kesiangan masuk sekolah, harus tegas untuk menegur. Kalau ada guru yang kesusahan harus segera tanggap untuk membantunya, di situlah saya berperan sebagai orang tua.

4. Kepala sekolah harus bisa menggerakkan kinerja guru dan warga sekolah, kepala sekolah harus bisa dijadikan figur, panutan bagi bawahannya. Kepala sekolah harus mampu memaksimalkan partisipasi masyarakat dalam pengelolaan sekolah melalui pendekatan yang sesuai kultur masyarakat.

5. Mampu mengadakan pembaharuan di satuan pendidikan, dengan mengikuti pembaharuan sesuai dengan perkembangan jaman dan kebijakan pemerintah. Anak didik di sekolah akan kita didik menjadi pimpinan-pimpinan bangsa di masa yang kemajuan teknologi sudah sangat pesat (masa 20 - 30 th yang akan datang). Sehingga kita tidak mungkin mendidik anak-anak tanpa berorientasi ke depan. Hal ini sangat menuntut kepala sekolah untuk berinovasi, memberi pengalaman yang sebanyak-banyaknya kepada anak didik kita. Tidak mungkin seorang kepala sekolah tidak terus menambah ilmu, menambah wawasan agar mendapatkan hal-hal baru untuk pengembangan sekolah; sebagai motivator, kepala sekolah adalah orang pertama yang melakukan, sehingga bisa terus memotivasi guru dan warga sekolah untuk melakukan. Juga tidak mungkin, diera yang serba cepat (globalisasi) kepala sekolah tidak bertekad kuat untuk mengembangkan diri (Long Life Education). Bahkan sepanjang hayat kita harus mengembangkan diri dengan keinginan dan tekad yang kuat.

\section{PEMBAHASAN}

Berdasarkan hasil wawancara seperti tersaji di atas, aktifitas kepemimpinan kepala SD yang berhasil menjadi juara adalah mengakomodasikan semua guru yang mempunyai karakter yang berbeda, sehingga guru bisa bekerja sesuai tugas pokok dan fungsinya secara maksimal. Selain itu juga berkomunikasi bukan saja dengan guru, tetapi juga dengan orang tua, masyarakat; Memahami kondisi stakeholder dan prestasinya, serta memberi reward terhadap yang berprestasi. Berbagai kegiatan kepala sekolah ternyata sesuai dengan model temuan Darling-Hammond, LaPointe, Meyerson, Orr \& Cohen (2007), yang menyatakan bahwa dalam pelaksanaan kepemimpinannya, kepala sekolah perlu bekerja bersama langsung dengan guru untuk meningkatkan kualitas pembelajaran di kelas, yang disertai dengan penyediaan sumber dan sarana/prasarana yang memadai serta mengimbangi dengan program pengembangan profesional guru. Hal yang disebut terakhir yaitu penyediaan sumber dan sarana/prasarana yang mendukung pengembangan profesional guru, kepala sekolah bekerjasama dan menjadi motivasi, agar para guru berinovasi, memberi kesempatan untuk menambah/mengembangkan profesinya dengan mengikuti pelatihan, seminar, lokakarnya, dan atau penataran. 
Darling-Hammond, LaPointe, Meyerson, Orr \& Cohen (2007) menyatakan bahwa kepala sekolah yang efektif dalam kepemimpinannya selalu memantau perkembangan guru dalam mengajar dan keberhasilan siswa dalam belajar, para juara kepala SD Jawa Tengah ini ternyata juga melakukan dengan membuat program kunjungan kelas untuk memantau kemajuan guru dalam mengajar dan program kunjungan lapangan untuk memberi pengalaman yang sebanyak-banyaknya kepada anakanak di sekolah. Lebih lanjut, kepala sekolah yang efektif mereka temukan dalam kegiatan menfasilitasi guru dalam kegiatan ilmiah demi kemajuan sekolah, para kepala SD Juara ini membantu serta mendukung guru mengikuti pelatihan, seminar, lokakarnya, penataran dan menjadwalkan guru untuk mengikuti dan berperan-serta dalam kegiatan $\mathrm{KKG}$, dan studi banding ke SD lain yang lebih maju. Pada akhirnya, ditemukan ciri kepala sekolah efektif yang begitu strategis yaitu melakukan penggalangan partisipasi orang tua dan masyarakat dalam pendidikan dan pembelajaran, sejalan dengan temuan ini, para kepala SD Juara justru memaksimalkan partisipasi masyarakat dalam pengelolaan sekolah melalui pendekatan yang sesuai kultur masyarakat.

Bagaimana Kepala SD berprestasi dalam mengembangkan SD? Model Darling-Hammond, LaPointe, Meyerson, Orr \& Cohen (2007), menyatakan ada dua variabel moderator yang strategis yaitu proses seleksi, yang disertai dengan dukungan terhadap pengembangan guru dalam pengajarannya dan proses kegiatan yang berdampak secara organisasional. Seleksi yang dialami para kepala SD Juara difahami sebagai proses alamiah, sebagai kepala sekolah, mereka mampu mengadakan pembaharuan di SD dengan penuh bertanggung jawab dan berani menanggung resiko pada kebijakan yang dibuat dan dilaksanakan bersama stake-holder. Selain itu kepala SD juara juga mampu mengikuti perkembangan IPTEK dan Seni sesuai perubahan/perkembangan jaman; perkembangan IPTEK untuk kemajuan SD, yang ternyata berdampak pada kualitas pembelajaran.

Proses kegiatan yang berdampak secara organisasional seperti: pengembangan 'masyarakat pembelajar', dimulai dari keberanian kepala SD juara menerobos ke depan, untuk mencari pembaharuan-pembaharuan yang ada hubungannya dengan kemajuan pendidikan: sebagai contoh, untuk mendongkrak kinerja guru dan warga sekolah, dalam pengambilan keputusan harus dimusyawarahkan secara bersama-sama, membuat kebijakan dengan arif sehingga semua pihak bisa menerima dengan baik. Dalam perencanaan aras sekolah dan kelas, mengidentifikasi nilai kebanggaan masyarakat sekitar dan menjadikannya program unggulan SD; dituangkan dalam RAPBS sehingga tidak mengalami kendala dalam hal pembiayaan dan pelaksanaannya. Dalam mengembangkan sekolah, dimulai dari memotivasi guru dan siswa agar berinovasi, berani memutuskan untuk berubah dan selalu mengikuti perkembangan kemajuan ilmu pengetahuan dan teknologi. Dengan begitu dapat meningkatkan kedisiplinan semua warga sekolah, meningkatkan kualitas pembelajaran yang akhirnya dapat meningkatkan kualitas out put.

Keberhasilan para Kepala SD juara ternyata dipengaruhi oleh 3 faktor yaitu: kepribadian, pemahaman/pengetahuan dan keterampilan sesuai tugas pokok dan fungsinya. (1) Kepribadian yang kuat yaitu: jujur, bertanggung jawab, demokratis, transparan, berwibawa, pantang menyerah. bersikap adil kepada teman kerja (tidak diskriminatif), berperilaku yang baik dan bertanggung jawab dalam tugasnya. Jadi figur, panutan bagi bawahannya. Mampu mengambil keputusan dengan baik, yang diterima oleh semua pihak serta didukung dalam pelaksanaannya sehingga dapat membuat sekolah yang kondusif. (2) Pemahaman kepala sekolah menyangkut memahami visi dan misi sekolah dan pengetahuan tentang bidang tugasnya maupun bidang lain yang terkait. (3) Keterampilan profesional dan konseptual yang terkait dengan tugasnya. Faktor kebijakan pendidikan baik aras nasional, provinsi, dan kabupaten/kota ternyata tidak berpengaruh; penguasaan mereka masih belum memuaskan. 


\section{PENUTUP}

Tiga puluh lima kepala SD Jawa Tengah yang telah berhasil menjadi juara dalam pemilihan kepala SD berprestasi karena kepemimpinan yang paling strategis dalam: bekerja langsung bersama dengan guru untuk meningkatkan kualitas pembelajaran di kelas, menyediakan sumber dan sarana/ prasarana yang memadai yang diimbangi dengan pengembangan profesional guru, secara periodik memantau perkembangan guru dalam mengajar dan keberhasilan siswa dalam belajar, menfasilitasi guru dalam kegiatan ilmiah yang terkait dengan pendidikan demi kemajuan SD, dan penggalangan partisipasi orang tua dan masyarakat dalam pendidikan/pembelajaran SD.

Kiprah kepemimpinan mereka itu dimoderatori oleh dua variabel, pertama proses seleksi alamiah, yang disertai dengan dukungan dan pengembangan guru dalam pengajarannya, dan kedua proses organisasional seperti pengembangan 'masyarakat pembelajar', perencanaan aras sekolah dan kelas, pengembangan kurikulum, pembelajaran dan penilaian.

Keberhasilan para Kepala SD juara ternyata dipengaruhi oleh 3 faktor yaitu: kepribadian, pemahaman/pengetahuan dan keterampilan sesuai tugas pokok dan fungsinya. Faktor kebijakan pendidikan baik aras nasional, provinsi, dan kabupaten/kota ternyata tidak berpengaruh; penguasaan mereka masih belum memuaskan.

Pengalaman keberhasilan para kepala SD juara di Jawa Tengah ini merupakan pengalaman berharga yang perlu dipelajari karena dapat diterapkan di SD lain dengan melakukan beberapa adaptasi sesuai kondisi SD dan masyarakat setempat. Model berpikir dan analisis yang penulis kembangkan ini masih perlu diuji dengan penelitian lanjut yang lebih rijid.

\section{DAFTAR PUSTAKA}

Abu-Duhou, I. 2002. School-Based Management. Jakarta: Logos Wacana Ilmu.

Darling-Hammond, L., LaPointe, M., Meyerson, D., Orr. M. T., \& Cohen, C. 2007. Preparing School Leaders for a Changing World: Lessons from Exemplary Leadership Development Programs. Stanford, CA: Stanford University, Stanford Educational Leadership Institute.

Depdiknas. 2002. Manajemen Peningkatan Mutu Berbasis Sekolah. Jakarta: Dirjen Dikdasmen.

Dharma, S. 2006. Kepemimpinan Pengawas Sekolah: Mengembangkan Budaya Tanggungjawab. Jurnal Tenaga Kependidikan. Vol. 1, No. 2 Agustus 2006.

Dikmenum. 2005. Manajemen Peningkatan Mutu Berbasis Sekolah (Buku 1). Jakarta: Direktorat Pendidikan Menengah Umum, Departemen Pendidikan Nasional.

Fattah, H.N. 2003. Konsep manajemen berbasis sekolah (MBS) dan Dewan Sekolah. Bandung: Pustaka Bani Quraisy.

Human development index (HDI) Reuters AlertNet-Indonesia

Leithwood, Louis, Anderson and Wahlstrom. 2004. How leadership influences student learning: Review of research. Ontario Institute for Studies in Education at The University of Toronto

Martono, T. 2007. Kepemimpinan Kepala Sekolah, Kinerja Guru, Budaya Organisasi Sekolah, Pengaruhnya Terhadap Produktivitas Sekolah. Surakarta: UNS

Satmoko, R.S. 1999. Landasan kependidikan, pengantar ke arah ilmu Pendidikan Pancasila. Semarang: CV IKIP Semarang Press. 